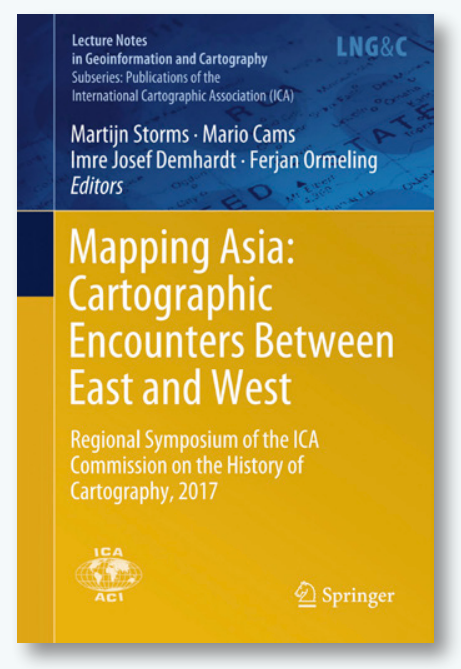

\title{
MAPPING ASIA: CARTOGRAPHIC ENCOUNTERS BETWEEN EAST AND WEST
}

Edited by Martijn Storms, Mario Cams, Imre Josef Demhardt, and Ferjan Ormeling

Springer International Publishing, 2019

299 pages

Hardcover: \$219.99, ISBN 978-3-319-90405-4

eBook: \$169.00, ISBN 978-3-319-90406-1

Review by: Jasmin Khangura

Mapping Asia: Cartographic Encounters Between East and West is a collection of sixteen research papers that were presented at Leiden University Library as part of the Regional Symposium of the ICA Commission on the History of Cartography in 2017. The focus of the conference-and consequently of the book-is the interaction and exchange between Asian and Western cartographic practices.

The book starts off with "The Topographic Survey of the Netherlands East Indies, Batavia 1864-1950,” an essay from one of the editors, Ferjan Ormeling. It begins by describing the topographic surveys compiled by the Royal Netherlands East Indies Army between 1864 and 1886. The maps in this series received several world prizes at world exhibitions, due largely to the advanced reproduction process employed in their publication. The Royal Netherlands East Indies Army itself, however, was dissatisfied, and the maps subsequently went through a number of revisions. The army's mapping brigades were originally staffed almost exclusively by Europeans, but as the years went by, more and more local surveyors were employed, and by 1950 the entire survey had been transferred to Indonesian authorities.

In the next essay, "The Importance of Diacritics on Dutch Historical Map Toponyms in Java, Aceh and Nias," Albina Apriadsa, Ari Cahyono, and Rossaydiana Apriadna make clear the importance of diacritics- the marks below or above a letter-to mapping a diverse country like Indonesia, where over 700 languages are spoken. Diacritics were used extensively on official Dutch East Indies maps from about 1900 through the 1920s, but were phased out in the 1930s. The authors examine the effect this omission of diacritics has had on the present-day spelling and pronunciation of toponyms, and suggest the use of the International Phonetic Alphabet as a way to preserve the spelling and pronunciation of the many languages in Indonesia.

The third essay is "Buginese Charts: Typical Cartographic Encounters Between East and West?" by Marco van Egmond, and focuses on a chart of the East Indian Archipelago written in Buginese, a language spoken in southern Indonesia. He compares this map with two other Buginese charts. The author concludes that the Buginese charts are a "hybrid" mix of Western and Indigenous cartography. Van Egmond believes that the charts were likely drawn by indigenous cartographers, who based their work on d'Après de Mannevillette's 1745 survey map of the East Indian Archipelago.

Next, Tsung-jen Chen revisits the popular Selden Maplikely produced in the early seventeenth century and depicting China, Korea, Japan, and parts of Southeast Asia. In "A Collage of Many Things: Rethinking the Making of the Selden Map," Chen concludes that the Selden Map was not created from first-hand knowledge, but was instead created using a variety of maps, charts, and information from both European and East Asian sources. 
"Jesuit Contribution to the Mapping of the Philippine Islands: A Case of the 1734 Pedro Murillo Velarde's Chart," by Mirela Altić, discusses how Velarde made the most detailed and accurate map of the Philippines up to that time. Altić stresses Velarde's rejection of the then-current Spanish representation of Philippines as part of the Americas, and substituted a conception of the Philippines as a separate entity.

Following this is Peter Kang's "Naming and Re-naming on Formosa: The Toponymic Legacies of the VOC Cartographies on the Eighteenth and Nineteenth Century Western Maps.” Kang explores how the toponyms found on seventeenth century Dutch East India Company (Vereenigde Oostindische Compagnie, or VOC) maps continued to be used on Western maps for the next two centuries. The survival of these toponyms alongside later geographical information is examined using maps depicting the island of Formosa-modern-day Taiwan.

Sayoko Sakakibara then discusses how the traditional Buddhist worldview of many Japanese was overturned in the mid-sixteenth century by their encounter with European geography in "Localizing Asia: Mapping Japan, Asia, and Europe in the Early Modern World.” There were three sacred countries in the Buddhist worldview: China, India, and Japan; the first two remained always at the center. The European worldview was somewhat different, and while some Japanese were reluctant to adopt it, others, like the geographer Nishikawa Joken, saw it as a chance to depict Japan as more than geographically peripheral to India and China.

In the eighth essay, "Gyoki-Type Shape: Representation of the Japanese Archipelago in East-Asian and Western Maps," Ekaterina Simonova-Gudzenko discusses the work of Gyōki Bosatsu, a Korean monk who was said to have founded mapmaking in Japan, and the influence his geographic representation of Japan exerted on both East Asian and Western representations of the Japanese archipelago. The unique characteristics of "Gyoki-type" maps are illustrated; for example, showing Japan with 66 named provinces and giving the number of districts in each is a typical "Gyoki-type" map feature. Evidence of their widespread use is noted on a variety of maps through numerous photographs.

Radu Leca contributes an analysis of nineteenth century Japanese maps in the collection of Leiden University that focuses on the exchanges of geographic knowledge that took place both between the Europeans and Japanese, and within each group. In "Maps as Knowledge Vehicles: Insights from the Collections of Leiden University Library," the author notes that maps were part of a system of reciprocal gift-giving traditions for both the Europeans and Japanese. Furthermore, both mapmakers and map users recognized their common interest in the increase of geographic knowledge and understanding.

Then, in "The Use of Japanese Early Modern Maps by Western Cartographers During the Nineteenth Century," Kunitada Narumi and Shigeru Kobayashi focus on how a 1779 map of Japan by Sekisui Nagakubo-the earliest accurately detailed Japanese map widely available in the West-contributed to the 1827 nautical chart of Russian navigator Adam Johann von Krusenstern.

A seventeenth century Chinese map by the lesser known scholar Cao Junyi is analyzed by Gang Song in "Relocating the 'Middle Kingdom': A Seventeenth-Century Chinese Adaptation of Matteo Ricci's World Map." Cao's map is a hybrid of two very different cartographic traditions-European and Chinese-and Song contends that it demonstrates that there was not a simple give-and-take relationship between Jesuit scholars-such as Matteo Ricci-and their Chinese counterparts. In his discussion of the mutual influence of Chinese and European cartographers, he also examines the ways Chinese cartography influenced Ricci: for example, Ricci's use of Chinese pictorial symbols and relocation of the prime meridian from the Atlantic to the Pacific.

In "Cartographic Accuracy and the Myth of Manchu Origins on the 1719 Overview Maps of the Imperial Territories," Fresco Sam-Sin writes about how Elhe Taifin, the fourth Khan of the Daiqing Empire, made use of a series of territorial "Overview Maps" as an element in an imperial, identity-building narrative.

The Royal Geographic Society solicited advice from the geographer William Huttman soon after the signing of the 1842 Treaty of Nanjing and the opening of five Chinese coastal ports to foreign trade. Huttman delivered his recommendations in 1844 , in which he especially advised the use of Chinese geographical works that had been prepared using firsthand accounts. Ines Eben von Racknitz discusses Huttman's suggestions in "Mapmakers in China and Europe 1800-1844: The Perspective of William 
Huttmann, Royal Geographical Society,” but was not, unfortunately, able to find out if the Royal Geographic Society had acted on them.

In the fourteenth essay, "From 'All Under Heaven' to 'China in the World': Chinese Visual Imaginations from the Nineteenth and Early Twentieth Centuries," Laura Pflug examines how increasing globalization in the late nineteenth and early twentieth centuries forced Chinese intellectuals to come to terms with non-Sinocentric worldviews. Pflug discusses the ways in which this reconciliation process took place, using a sizable number of visuals to illustrate how the cartographic representation of China changed over time.

Pflug's essay is followed by "A Disastrous Project: C. P. Keller and the Fortification (Plans) of Bimilipatnam" by Jeroen Bos. In the mid-eighteenth century, the Dutch East India Company commissioned the engineer Coenraad Pieter Keller to draw up fortification plans for the Indian village of Bimilipatnam. Keller produced a general overview map of the town and its surroundings, plus an annotated plan of the proposed fortification. Although at first appointed to oversee the work, Keller was later blamedperhaps unfairly-for two construction collapses, just as he had been blamed for cost overruns on earlier projects.

Finally, in "Inventing a Cartographical Image for Postcolonial India: European Models and the Politics of National Identity," Arundhati Virmani looks at S. P. Chatterjee's 1957 publication of India's first post-independence atlas. The atlas consisted of twenty-six pages, each with a different map, and was intended to help establish a unified identity for the new nation among both Indians and others. This intention was also served by the decision to publish in Hindi-one of the new country's two official languages, alongside English-despite the fact that, as Virmani notes, the script was unfamiliar at the time even to most people who spoke that language. In addition, Virmani also points out how much the production of the atlas drew upon foreign institutions and people trained in Britain and Europe. Chatterjee himself had trained in France and was an active participant in international cartographic conferences.
The collection of sixteen essays in Mapping Asia: Cartographic Encounters Between East and West provides a rare cross-disciplinary analysis of the impacts that Western and Eastern cartography had on one another between the sixteenth and twentieth centuries, and also sparks interest in examining further such encounters. Understandably, one book can only cover so much.

The editors provided a preface, which sets the scene for the essays, but did not provide any concluding remarks. A wrap-up chapter or epilogue would have been helpful in highlighting what the editors deemed to be the most important takeaways from the collection.

While Mapping Asia is unique in not solely focusing on the contributions of Western scholarship, there are some essays in which the Western influence on cartography dominates and the Eastern/indigenous contribution is barely mentioned. One example is Jeroen Bos's article, where the Indian village of Bimilipatnam serves only as a backdrop for Keller's military engineering.

The book has plenty of color images; however the maps are very small and not clearly reproduced. This is to a certain extent understandable, as it is difficult to fit large illustrations on a small page, but in the twenty-first century it is not clear why high-resolution images of all the maps are not available online. Peter Kang was the only author to post URLs of high-resolution digital copies of the maps he discussed. Panning and zooming through the maps was very helpful, and I had a much better understanding of his article because of it.

At $\$ 220$ for the hardcopy, and $\$ 169$ for the eBook, this title is exorbitantly priced-especially for students and young professionals. However, some or all of these essays may be freely accessible through university libraries. Mapping Asia: Cartographic Encounters Between East and West is an original collection of essays that is neither organized nor written for the general public. The essays are academic articles intended for academic use by university professors, researchers, or students. That said, for those academicians with an interest in Eastern and Western cartographic history, this book is an invaluable resource. 